\title{
Satellite quantification of oil and natural gas methane emissions in the US and Canada including contributions from individual basins
}

Lu Shen ${ }^{1,2,3 *}$, Ritesh Gautam ${ }^{3}$, Mark Omara ${ }^{3}$, Daniel Zavala-Araiza ${ }^{3,4}$, Joannes D. Maasakkers ${ }^{5}$, Tia R. Scarpelli², Alba Lorente, David Lyon ${ }^{3}$, Jianxiong Sheng, ${ }^{6}$, Daniel Varon ${ }^{2}$, Hannah Nesser ${ }^{2}$, Zhen $\mathrm{Qu}^{2}$, Xiao Lu ${ }^{2,7}$, Melissa P.

5 Sulprizio $^{2}$, Steven P. Hamburg ${ }^{3}$, Daniel J. Jacob ${ }^{2}$

${ }^{1}$ Department of Atmospheric and Oceanic Sciences, School of Physics, Peking University, Beijing 100871, China

${ }^{2}$ School of Engineering and Applied Sciences, Harvard University, Cambridge, Massachusetts 02138, United States

${ }^{3}$ Environmental Defense Fund, Washington DC 20009, United States

$10{ }^{4}$ Institute for Marine and Atmospheric Research Utrecht, Utrecht University, 3584 CC, Utrecht, The Netherlands ${ }^{5}$ SRON Netherlands Institute for Space Research, Leiden, the Netherlands

${ }^{6}$ Center for Global Change Science, Massachusetts Institute of Technology, Cambridge, Massachusetts 02139, United States

${ }^{7}$ School of Atmospheric Sciences, Sun Yat-sen University, Zhuhai, Guangdong, China 519082

Correspondence to: Lu Shen (1shen@pku.edu.cn)

Abstract. We use satellite methane observations from the Tropospheric Monitoring Instrument (TROPOMI), from May 2018 to February 2020, to quantify methane emissions from individual oil and natural gas $(\mathrm{O} / \mathrm{G})$ basins in the US and Canada using a high-resolution $(\sim 25 \mathrm{~km})$ atmospheric inverse analysis. Our satellite-derived emission estimates show good consistency with in-situ field measurements $\left(R^{2}=0.92\right)$ in $14 \mathrm{O} / \mathrm{G}$ basins distributed across the US and Canada. Aggregating our results to the national scale, we obtain O/G-related methane emission estimates of $12.6 \pm 2.1 \mathrm{Tg} \mathrm{a}^{-1}$ for the US and 2.2 \pm 0.6 $\mathrm{Tg} \mathrm{a}^{-1}$ for Canada, respectively $80 \%$ and $40 \%$ higher than the national inventories reported to the United Nations. About $70 \%$ of the discrepancy in the EPA inventory can be attributed to five O/G basins: the Permian, Haynesville, Anadarko, Eagle Ford and Barnett Basin, which in total account for $40 \%$ of US emissions. We show more generally that our TROPOMI inversion framework can quantify methane emissions exceeding $0.2-0.5 \mathrm{Tg} \mathrm{a}^{-1}$ from individual $\mathrm{O} / \mathrm{G}$ basins, thus providing an effective tool for monitoring methane emissions from large $\mathrm{O} / \mathrm{G}$ basins globally.

\section{Introduction}

Increasing atmospheric methane has driven a $0.5^{\circ} \mathrm{C}$ global warming since 1850 , making methane abatement a critical means to limit future warming (IPCC, 2021). Methane emissions have a warming potential 80 times higher than carbon dioxide over a 20-year horizon (Myhre et al., 2013; Ocko et al., 2021). Methane is the primary component of natural gas which is an increasingly important energy source in the US and Canada, accounting for a third of national energy consumption in 2019 (US International Energy Agency, https://www.iea.org/). The production of oil and gas $(\mathrm{O} / \mathrm{G})$ in the US has more than doubled since 2005 (Enverus DrillingInfo, 2020), raising concerns about the climate impacts from methane emissions. National greenhouse gas emission inventory data reported to the United Nations Framework Convention on Climate Change 
35 (UNFCCC) by the US Environmental Protection Agency (EPA) and Environmental and Climate Change Canada (ECCC) governmental agencies report methane emissions from $\mathrm{O} / \mathrm{G}$ sectors of $7.0 \mathrm{Tg} \mathrm{a}^{-1}$ in the US and $1.6 \mathrm{Tg} \mathrm{a}^{-1}$ in Canada in 2018 (EPA, 2020; ECCC, 2020), accounting for 13\% of global O/G methane emissions (Scarpelli et al., 2020).

Emission inventories reported to the UNFCCC are based on 'bottom-up' estimates by applying emission factors to activity data. Many 'top-down' studies using measurements of atmospheric methane have shown that the national $\mathrm{O} / \mathrm{G}$ methane emission inventories in the US and Canada are biased low (Brandt et al., 2014; Alvarez et al., 2018; Omara et al., 2018; Maasakkers et al., 2021; Johnson et al., 2017; MacKay et al., 2021). Alvarez et al. (2018) estimated the US O/G methane emissions in 2015 as $13 \pm 2 \mathrm{Tg} \mathrm{a}^{-1}$ by extrapolating field observations from $9 \mathrm{O} / \mathrm{G}$ production basins, and found the emissions to be $60 \%$ higher than EPA estimates. Maasakkers et al. (2021) and Lu et al. (2021b) inferred a factor of 2 underestimate in EPA oil emissions by inversion of Greenhouse Gases Observing Satellite (GOSAT) data. Ground-based and satellite observations for the Permian Basin, the largest oil-producing basin in the US, indicate an emission source of 2.7-3.2 $\mathrm{Tg} \mathrm{a}^{-1}$ (Zhang et al., 2020; Schneising et al., 2020; Robertson et al., 2020; Lyon et al., 2021), 3 times higher than expected based on the EPA reported data. Field and GOSAT measurements over Canada similarly show a factor of 1.5 or greater underestimate of O/G emissions in the ECCC inventory(Johnson et al., 2017; Baray et al., 2018, 2021; Atherton et al., 2017; Lu et al., 2021b). A likely reason to explain the large discrepancy between the national emission inventories and

50 atmospheric measurements is that the inventories do not properly account for the heavy-tailed emissions due to abnormal operating conditions and malfunctions, including fugitive emissions from venting, leakage, inefficient flaring, and blowouts (Brandt et al., 2014; Zavala-Araiza et al., 2021; Alvarez et al., 2018; Pandey et al., 2019; Duren et al., 2019; Lyon et al., 2021; Rutherford et al., 2021).

While inversion of GOSAT satellite observations has emerged as a powerful tool to quantify methane emissions from different sectors (such as $\mathrm{O} / \mathrm{G}$ ) on global and continental scales (Cressot et al., 2014; Alexe et al., 2015; Maasakkers et al., 2019; Lu et al., 2021a; Turner et al., 2015; Zhang et al., 2021), GOSAT data has limited skill on regional scales because individual sampling tracks are separated by $\sim 270 \mathrm{~km}$. On the other hand, field campaigns can characterize emissions on regional scales(Alvarez et al., 2018) and from point sources (Frankenberg et al., 2016; Duren et al., 2019), but they are limited in their spatial extent and temporal duration, which is problematic because of the temporal variability and intermittency of emissions (Cusworth et al., 2021; Varon et al., 2021; Lyon et al., 2021).

The Tropospheric Monitoring Instrument (TROPOMI) onboard Sentinel-5P is a recent satellite mission which provides daily methane observations from satellite at $\sim 7 \mathrm{~km}$ spatial resolution (at nadir) starting in May 2018 (Lorente et al., 2020), considerably increasing the potential for monitoring regional methane emissions from space (Schneising et al., 2020; Zhang et al., 2020; Shen et al., 2021). Here we exploit TROPOMI to better quantify methane emissions from all major O/G 65 production basins in the US and Canada with a high-resolution $(\sim 25 \mathrm{~km})$ inversion of 22 months of data, and using the most 
recent gridded versions of the EPA and ECCC inventories as prior estimates (Maasakkers et al., 2016; Scarpelli et al., 2021). Our inversion uses an analytical method that provides closed-form error characterization as part of the solution, and enables an ensemble approach to assess the sensitivity of the results to the choices of inversion parameters and data filters. This allows us to evaluate the ability of TROPOMI to quantify methane emissions from an individual $\mathrm{O} / \mathrm{G}$ basin as a function of

70 source and observation characteristics. From there we draw general conclusions about the emerging role of satellite observations in quantifying regional methane emissions and evaluating bottom-up emission inventories.

\section{Data and Methods}

\subsection{Satellite observations}

75 We use a beta version of the operational TROPOMI methane retrieval product (Lorente et al., 2020) for the period May 2018 - February 2020. TROPOMI is onboard the polar sun-synchronous Sentinel-5 Precursor satellite with a 13:30 local overpass time, and provides daily global coverage in cloud-free conditions with $7 \mathrm{~km} \times 7 \mathrm{~km}$ spatial resolution at nadir $(7 \mathrm{~km}$ x $5.5 \mathrm{~km}$ since August 2019) (Hu et al., 2016; Veefkind et al., 2012). The column-averaged methane dry mixing ratio $\left(\mathrm{XCH}_{4}\right)$ is retrieved using the sunlight backscattered by the Earth's surface in the shortwave infrared (SWIR) $2.3 \mu \mathrm{m}$ spectral band

80 using the RemoTeC full-physics algorithm with near-uniform sensitivity down to the surface. We do not consider observations after February 2020 because the Covid-19 pandemic could significantly affect O/G related emissions(Lyon et al., 2021). We only use good quality $\mathrm{XCH}_{4}$ retrievals that meet the following recommended criteria: (1) qa_value $\geq 0.5$, (2) blended albedo $<=0.85$, and (3) surface altitudes $<=2 \mathrm{~km}$ (Fig. S1). The blended albedo can be used to filter scenes covered by snow(Wunch et al., 2011). The total number of TROPOMI observations is 7x10 in the US and Canada for May $2018-$

85 February 2020 . The number of observations per $0.25^{\circ} \times 0.3125^{\circ}$ inversion grid cell is typically in the $100-1000$ range and exceeds 1000 in the Southwest US (Fig. S2).

When validated with the ground-based measurements from the Total Column Carbon Observing Network (TCCON), TROPOMI $\mathrm{XCH}_{4}$ has a mean global bias of $-3.4 \pm 5.6 \mathrm{ppb}$ and a regional bias of $6.4 \pm 4.1 \mathrm{ppb}$ for the US(Lorente et al., 2020). We also intercompared the TROPOMI data with Greenhouse gases Observing SATellite (GOSAT) data from the University 90 of Leicester version 9.0 Proxy $\mathrm{XCH}_{4}$ retrieval(Butz et al., 2011; Parker et al., 2020) and find the mean TROPOMI-GOSAT difference to be $-5.4 \pm 6.9 \mathrm{ppb}$ in North America (Fig. S3). The mean bias in the TROPOMI data is effectively corrected in the specification of boundary conditions. The regional bias (standard deviation of the mean bias) is below the 10 ppb threshold recommended by Buchwitz et al. (2015) for successful inversions.

\subsection{Gridded national bottom-up inventories}

95 Prior anthropogenic methane emissions in the US and Canada are from the sector-resolved national inventories produced by the EPA (Inventory of U.S. Greenhouse Gas Emissions and Sinks) and ECCC and spatially allocated to a $0.1^{\circ} \mathrm{x} 0.1^{\circ}$ grid by 
Maasakkers et al. (2016) for the US in 2012 and Scarpelli et al. (2021) for Canada in 2018. We extrapolated the US emissions for the $\mathrm{O} / \mathrm{G}$ production sector to 2018 based on upstream well data in the Enverus DrillingInfo database (Enverus DrillingInfo, 2020) together with EPA national totals for O/G production, gas processing, transmission, and distribution (EPA, 2020). Prior anthropogenic emission totals for the continental US and Canada are $31.7 \mathrm{Tg} \mathrm{a}^{-1}$ with major contributions from livestock (10.7 $\left.\mathrm{Tg} \mathrm{a}^{-1}\right)$, oil and gas (8.6 $\mathrm{Tg} \mathrm{a}^{-1}$ with $7.0 \mathrm{Tg} \mathrm{a}^{-1}$ for the US and $1.6 \mathrm{Tg} \mathrm{a}^{-1}$ for Canada), landfills (6.4 $\mathrm{Tg} \mathrm{a}^{-}$ ${ }^{1}$ ), coal $\left(3.2 \mathrm{Tg} \mathrm{a}^{-1}\right)$, wastewater treatment $\left(0.72 \mathrm{Tg} \mathrm{a}^{-1}\right)$ and others. Prior wetland emissions with $0.5^{\circ} \times 0.5^{\circ}$ spatial resolution for individual months are taken from the mean of the nine highest-performance members of WetCHARTS v1.3.1 inventory ensemble (Ma et al., 2021). Fig. S4 shows the distribution of the prior methane emissions over the study domain. Although the EPA and ECCC bottom-up inventories report oil and gas emissions separately, spatial overlap between the two makes specific attribution difficult in an inversion (Enverus DrillingInfo, 2020), and we therefore combine them here.

\subsection{GEOS-Chem forward model simulations and inverse model setup}

We use the GEOS-Chem 12.7.0 chemical transport model (https://doi.org/10.5281/zenodo.1343546) as the forward model to relate methane emissions to the atmospheric methane columns observed by TROPOMI. GEOS-Chem is driven by GEOS-FP reanalysis meteorological fields from the NASA Global Modeling and Assimilation Office (GMAO) (Lucchesi, 2013) with $0.25^{\circ} \times 0.3125^{\circ}$ resolution. Here we use a nested version of GEOS-Chem with $0.25^{\circ} \times 0.3125^{\circ}$ horizontal resolution and dynamic boundary conditions from a $4^{\circ} \times 5^{\circ}$ global simulation. Following Shen et al. (2021), we ensure that model boundary conditions are consistent with TROPOMI observations by scaling the GEOS-Chem vertical fields in each boundary grid square and for each day to match the TROPOMI column observations averaged over the neighboring $\pm 1,000 \mathrm{~km}$ and \pm 15 days.

The inversion optimizes a state vector defined by gridded methane emissions for the domain of interest. This involves computing the sensitivity of methane concentrations to perturbation of emissions from each state vector element in GEOSChem in order to construct the Jacobian matrix. Doing so at high resolution $\left(0.25^{\circ} \times 0.3125^{\circ}\right)$ is readily done on a highperformance cluster as a parallel problem but is nevertheless expensive. To reduce the computational cost, we limit the highresolution inversion to the five domains where the O/G sources in the US and Canada are concentrated (Fig. 1 and more details in Fig. S5).

In each domain, we construct the state vector as follows. First, all native $0.25^{\circ} \times 0.3125^{\circ}$ gridcellswith prior $\mathrm{O} / \mathrm{G}$ emissions $>0.5 \mathrm{Gg} \mathrm{a}^{-1}$ are treated as independent state vector elements These gridcells account for $93 \%$ of total $\mathrm{O} / \mathrm{G}$ emissions in the US and Canada. Second, we aggregate gridcells that are inside each domain but with $\mathrm{O} / \mathrm{G}$ emissions $<0.5$

$125 \mathrm{Gg} \mathrm{a}^{-1}$ into clusters using a k-means algorithm based on features including prior emissions from each sector and adjacency, following Turner and Jacob (2015). The average size of these clusters is $1^{\circ} \times 1^{\circ}$ and they allow us to retrieve another $5 \%$ of total $\mathrm{O} / \mathrm{G}$ emissions in the US and Canada, adding up to $98 \%$. Third, we aggregate gridcells that are outside each domain but 
are within $4^{\circ}$ in distance into 16 clusters using the k-means algorithm based on adjacency (Fig. S6), following Shen et al. (2021). These clusters are designed to correct for errors in boundary conditions, and they are not used for $\mathrm{O} / \mathrm{G}$ source attribution. Altogether, the model estimates 3650 independent flux variables in the United States and Canada (Table S2).

\subsection{Atmospheric inverse analysis}

We solve for the posterior estimates of methane emissions (state vector $\boldsymbol{x}$ ) in the US and Canada using Bayesian inverse analysis with Gaussian error statistics. The inversion finds the optimal estimate of $\boldsymbol{x}$ by minimizing the cost function $J$ given by

$$
J(x)=\left(x-x_{A}\right)^{T} S_{A}^{-1}\left(x-x_{A}\right)+\gamma(y-K x)^{T} S_{o}^{-1}(y-K x)
$$

where $\boldsymbol{x}_{A}$ is the prior estimate, $\boldsymbol{K}$ is the Jacobian matrix, $\boldsymbol{y}$ is the vector of TROPOMI observations, $\boldsymbol{S}_{\boldsymbol{A}}$ and $\boldsymbol{S} \boldsymbol{o}$ are covariance matrices for prior and observational errors, and $\gamma$ is an additional regularization factor (Brasseur, and Jacob, 2017). We construct the observational error covariance matrix $\boldsymbol{S}_{\boldsymbol{O}}$ by applying the residual error method, which assumes that the statistics of residual error (after removing the mean bias) between the observations and a GEOS-Chem simulation with prior emissions defines the observational error variance (Heald et al., 2004; Wecht et al., 2014). For native gridcells, we assume $50 \%$ error standard deviation for all anthropogenic and natural emissions on the $0.25^{\circ} \times 0.3125^{\circ}$ grid. For the gridcell clusters, we assume the error standard deviation to be $\frac{50 \%}{\sqrt{\mathrm{p}}}$, where $p$ is the number of gridcells in each cluster.

The analytical solution for $\nabla_{\mathrm{x}} J(\mathrm{x})=0$ yields the optimal estimate $\widehat{x}$ for the state vector, the corresponding posterior error covariance matrix $\widehat{\boldsymbol{S}}$, and the averaging kernel matrix $\boldsymbol{A}$ as follows

$$
\begin{aligned}
& \widehat{x}=x_{A}+\left(\gamma K^{T} S_{o}^{-1} K+S_{A}^{-1}\right)^{-1} \gamma K^{T} S_{o}^{-1}\left(y-K x_{A}\right) \\
& \widehat{S}^{-1}=\gamma K^{T} S_{o}^{-1} K+S_{A}^{-1} \\
& A=I-\widehat{S} S_{A}^{-1}
\end{aligned}
$$

where $\boldsymbol{I}$ is the identity matrix. The averaging kernel matrix $\boldsymbol{A}$ defines the sensitivity of the posterior solution to the true state, and the diagonal terms of $\boldsymbol{A}$ are the averaging kernel sensitivities diagnosing the ability of the inversion to quantify emissions for the corresponding state vector elements independently of the prior estimates. The trace of $\boldsymbol{A}$ quantifies the degrees of freedoms for signal (DOFS), representing the number of independent pieces of information that can be effectively optimized in the inversion (Brasseur, and Jacob, 2017). 
The regularization term $\gamma$ is intended to account for unresolved observational error covariances in the inversion and thus to avoid overfit to observations. Following Lu et al. (2021a), we choose $\gamma$ such that $\left(\widehat{\boldsymbol{x}}-\boldsymbol{x}_{\boldsymbol{A}}\right)^{\boldsymbol{T}} \boldsymbol{S}_{A}{ }^{-1}\left(\widehat{\boldsymbol{x}}-\boldsymbol{x}_{\boldsymbol{A}}\right) \approx n$ where $n$ is the number of state vector elements, as would be expected from a chi-square distribution. This yields $\gamma$ in the range $0.1-0.4$ with a best estimate of 0.2 (Fig. S7).

We evaluate the inversion by comparing the column-averaged methane from TROPOMI with GEOS-Chem simulations using prior and posterior estimates (Fig. S8). The prior simulation has a negative bias of 10-15 ppb across most O/G basins and a positive bias of 10-20 ppb in the central and eastern US. GEOS-Chem simulations based on posterior estimates (as shown in Fig. 2) can reduce the negative bias to $0-10 \mathrm{ppb}$ in most $\mathrm{O} / \mathrm{G}$ basins and especially in the southwestern US where the TROPOMI observation frequency is highest and our inversion system has the highest sensitivity to emissions (Fig. S2 and S9).

\subsection{Partitioning the oil and natural gas emissions.}

Following Shen et al. (2021), we write the sectorial posterior correction for each pixel as

$$
\begin{gathered}
f_{i}=\frac{\eta \alpha_{i} \sigma_{i, \text { nation }}^{2}\left(f_{0}-1\right)}{\sigma_{0}^{2}}+1 \quad(1 \leq \mathrm{i} \leq \mathrm{M}) \\
\eta=\frac{\sigma_{0}^{2}}{\sum_{i=1}^{M} \alpha_{i}^{2} \sigma_{i, \text { nation }}^{2}}
\end{gathered}
$$

Where $\alpha_{i}$ is the fraction of emissions of each sector taken from the prior and $f_{i}$ is the posterior correction factor for $i^{\text {th }}$ sector in this gridcell, $f_{0}$ is the posterior scaling factors, $\sigma_{0}$ is the prior error standard deviation, $M$ is the number of source sectors, the 'nation' index refers to the error standard deviations on the national totals obtained from Maasakkers et al. (2016) and Bloom et al. (2017). The posterior correction factor will be adjusted more for a specific sector if this sector has higher percentage in the total emissions and higher prior uncertainty.

\subsection{Inversion ensemble and uncertainty analysis}

Starting from the baseline inversion as described above, we conducted an ensemble of sensitivity inversions to test the robustness of our results to different inversion parameters and selection of TROPOMI observations. The 24-member ensemble includes: (1) setting the regularization factor $\gamma$ to 0.1 and 0.4 (0.2 in baseline); (2) increase the prior $\mathrm{O} / \mathrm{G}$ emissions by $50 \%$ (EPA and ECCC in baseline); (3) prior error standard deviation of $75 \%$ ( $50 \%$ in baseline); (4) removal of TROPOMI data with shortwave infrared albedo $<0.05$ (12\% of total TROPOMI observations). We then use the Monte Carlo method to estimate the posterior uncertainty from the ensemble (2,400 samples are generated for each gridcell). We report error statistics on the inversion results as two standard deviations $(2 \sigma)$, corresponding to the $95 \%$ confidence level. 


\section{Quantification of oil and natural gas emissions in the US and Canada using TROPOMI}

Fig. 1a shows the spatial distribution of TROPOMI column-averaged dry-air mole fraction of methane $\left(\mathrm{XCH}_{4}\right)($ Lorente et al., 2020) in the US and Canada from May 2018 to February 2020. The largest enhancements are along the southeastern coastal areas and the Mississippi River where wetland emissions are the dominant source (Fig. S10). Anthropogenic enhancements are also apparent in $\mathrm{O} / \mathrm{G}$ basins including the Central Valley in California, the Permian Basin, the Anadarko Basin, the Dallas Ft. Worth - Barnett Shale area, and southwestern Pennsylvania. Fig. 1b shows the bottom-up O/G methane emissions from the US and Canada in 2018 based on the gridded versions of the EPA and ECCC national inventories(Maasakkers et al., 2016; Scarpelli et al., 2021), which are used as prior estimates in our inversion framework. Here the original gridding of US EPA emissions for the year 2012 (Maasakkers et al., 2016) has been extrapolated to 2018

190 on the basis of the updated national inventory (EPA, 2020) and updated information about O/G wells (Enverus DrillingInfo, 2020), as described in the Methods.

We conduct inversions of TROPOMI observations for 22 months (May 2018 - February 2020) in the five rectangular domains of Fig. 1a, which encompass over $98 \%$ of total $\mathrm{O} / \mathrm{G}$ emissions, $97 \%$ of oil production and $99 \%$ of gas production in the continental US and Canada (Enverus DrillingInfo, 2020; Maasakkers et al., 2016; Scarpelli et al., 2021), and include all

19519 major O/G production basins shown in Fig. $1 \mathrm{~b}$ (see Fig. S11 for the names of these basins). The inversions are conducted at $0.25^{\circ} \times 0.3125^{\circ}$ (latitude $\mathrm{x}$ longitude) resolution in the $\mathrm{O} / \mathrm{G}$ production basins and in other $\mathrm{O} / \mathrm{G}$-emitting grid cells, accounting for $93 \%$ of total $\mathrm{O} / \mathrm{G}$ emissions. Other grid cells are aggregated into clusters. We only use high-quality TROPOMI retrievals ( $7 \times 10^{6}$ retrievals for the study period) and evaluate them with GOSAT to check for regional bias. We further examine the effect of different data filters (see Methods for more details). We do not separate the emissions from oil and natural gas sectors because they are usually co-located spatially (Enverus DrillingInfo, 2020) and it is challenging to effectively distinguish between the two sources solely based on satellite data.

The inversion uses Bayesian optimization to infer the best (posterior) estimates of methane emissions for individual grid cells as determined from the combination of TROPOMI observations and the gridded emission inventories taken as prior estimates. This yields correction factors for emissions (ratios of posterior to prior estimates). Not all emissions are from the $\mathrm{O} / \mathrm{G}$ sector, so we attribute the correction factors to specific methane source sectors based on information from the gridded national inventories including the sector-specific error statistics, as described by Shen et al. (2021). As stated in the Methods, we conduct an ensemble of inversions to test the robustness of our results for different sensitivity parameters in the inverse modelling framework, including different weighting of observations, prior estimates and prior uncertainty, data selection, size of basin, sampling frequency, etc (see Methods for more details). We then use a Monte Carlo method to estimate the posterior uncertainty from the ensemble (2,400 samples are generated for each gridcell), and we report the error as two standard deviations $(2 \sigma)$ to facilitate comparison with the $95 \%$ confidence interval or the range of estimates reported in previous studies (Alvarez et al., 2018; Lu et al., 2021a). 
Fig. 2a shows the optimized posterior correction factors for $\mathrm{O} / \mathrm{G}$ emissions relative to the EPA and ECCC inventories (Fig. 1b). Fig. $2 b$ shows the corresponding posterior emissions, and Fig. $2 c$ shows the results for the $19 \mathrm{O} / \mathrm{G}$ basins. Although the national maps show patterns of upward and downward correction factors, emissions for the $19 \mathrm{O} / \mathrm{G}$ basins show general increases except for parts of the Marcellus basin in southwestern Pennsylvania, California's Central Valley and DenverJulesburg basin. Emissions are dominated by a small number of basins where the correction factors to the national inventories are in excess of 2, except for the Marcellus. The Permian basin is the largest basin-wide source $\left(2.9 \mathrm{Tg} \mathrm{a}^{-1}\right)$, a factor of 4.7 larger than the $0.62 \mathrm{Tg} \mathrm{a}^{-1}$ in the extrapolated gridded EPA inventory, and accounts for $25 \%$ of total US O/G emissions in the posterior estimate. The posterior uncertainty is $20 \%(2 \sigma)$ for the first 9 largest $\mathrm{O} / \mathrm{G}$ basins and $34 \%(2 \sigma)$ for the 10 smaller ones, indicating that TROPOMI can more effectively quantify the emissions from the larger basins.

The underestimate of emissions by the gridded EPA inventory in the Permian has been pointed out before using satellite observations including TROPOMI(Zhang et al., 2020), GOSAT(Maasakkers et al., 2021), imaging spectrometers (IrakulisLoitxate et al., 2021), and field studies(Lyon et al., 2021), and attributed in part to rapidly increasing oil and gas production (Zhang et al., 2020). Increasing our prior estimate of emissions in the Permian from $0.62 \mathrm{Tg} \mathrm{a}^{-1}$ to $2.2 \mathrm{Tg} \mathrm{a}^{-1}$ to reflect this knowledge increases our posterior estimate by $30 \%$ to $3.7 \mathrm{Tg} \mathrm{a}^{-1}$ (Fig. 2c, more details in Fig. S12), a relatively small response reflecting the strong information available from TROPOMI observations. Splitting the TROPOMI observations into two periods, and with prior estimates of 0.62-2.2 $\mathrm{Tg} \mathrm{a}^{-1}$, we find posterior emissions of 2.5-3.4 $\mathrm{Tg} \mathrm{a}^{-1}$ for May 2018 - March 2019 and 3.0-3.8 $\mathrm{Tg} \mathrm{a}^{-1}$ for April 2019 - February 2020, indicating an increase over the period. The $\mathrm{O} / \mathrm{G}$ emissions in the Delaware subbasin increases from 0.83 to $0.97 \mathrm{Tg} \mathrm{a}^{-1}$, in response to the changes of prior emissions from 0.12 to $0.45 \mathrm{Tg} \mathrm{a}^{-1}$. Assuming an average methane content of $90 \%$ for this natural gas, our posterior emission range of 2.9-3.7 $\mathrm{Tg} \mathrm{a}^{-1}$ corresponds to a 3.2-4.1\% loss rate (natural gas production in the Permian was $5.4 \times 10^{6} \mathrm{MMcf}$ from May 2018 to February 2020 (Enverus DrillingInfo, 2020)).

We derive national totals for $\mathrm{O} / \mathrm{G}$ emissions in the US and Canada by aggregating the posterior emissions from Fig. 2 and 235 retaining the prior EPA and ECCC estimates for $0.2 \mathrm{Tg} \mathrm{a}^{-1}$ of $\mathrm{O} / \mathrm{G}$ emissions outside the inversion domains (including Alaska). Fig. 3 compares our results to previous studies, most of which are for emissions before 2017. Our satellite-derived US estimate in 2018-2020 is $12.6 \pm 2.1( \pm 2 \sigma) \mathrm{Tg} \mathrm{a}^{-1}$, which is $80 \%$ higher than the bottom-up inventory reported by EPA (EPA, 2020) and the Emissions Database for Global Atmospheric Research (EDGAR version v6.0) (Crippa et al., 2020). About $70 \%$ of this underestimate is from five O/G basins, including the Permian, Haynesville, Anadarko, Eagle Ford and 240 Barnett, which are in total responsible for $40 \%$ of US O/G emissions (Fig. 2). Our US national estimate is comparable to the facility-based estimate for 2015 by Alvarez et al. (2018) that can better account for the heavy-tailed emissions and was found to be consistent with aircraft measurements. We find lower emissions than Alvarez et al. (Alvarez et al., 2018) in DenverJulesburg, Fayetteville, Uinta, West Arkoma, San Juan and Northeast Pennsylvania, which could be due to decreasing O/G production in these basins ( Fig. S13). This is offset by fast growing emissions in the Permian, where the O/G production 
almost doubled from 2015 to 2019 (Enverus DrillingInfo, 2020; Zhang et al., 2020). Our US national estimate for O/G emissions is also comparable to previous inversions of GOSAT and in-situ data for 2010-2017 (Lu et al., 2021b; Maasakkers et al., 2021), with Lu et al. (2021b) reporting increasing emissions in the oil-producing basins but decreasing emissions in gas-producing basins over the period. When normalized by annual natural gas production $\left(4.1 \times 10^{7}\right.$ MMcf, US EIA; assuming the average $\mathrm{CH}_{4}$ content is $90 \%$ ) in 2019, the national $\mathrm{O} / \mathrm{G}$ mean leakage rate (including all $\mathrm{O} / \mathrm{G}$ sectors) inferred from our work is $1.8 \%$ in the US.

Our top-down estimate in Canada is $2.2 \pm 0.6( \pm 2 \sigma) \mathrm{Tg} \mathrm{a}^{-1}$, which is $40 \%$ higher than the most recent ECCC reported emissions (ECCC, 2020) and EDGAR v6 (Crippa et al., 2020) in 2018, and is at the lower end of other top-down studies (2.3-3.6 Tg a $\mathrm{Tg}^{-1}$ ) for 2010-2017(Lu et al., 2021b; Baray et al., 2021; Maasakkers et al., 2021; Chan et al., 2020). This could be due to a decreasing trend of $\mathrm{O} / \mathrm{G}$ emissions after 2014 in Canada, as reported by both the bottom-up national inventory

255 (ECCC, 2020) and inversion studies (Lu et al., 2021b), and reflecting the ongoing regulations efforts following Canada's commitment to reduce $\mathrm{O} / \mathrm{G}$ methane emissions by $40-45 \%$ by 2025 relative to the 2012 level (ECCC, 2017). When

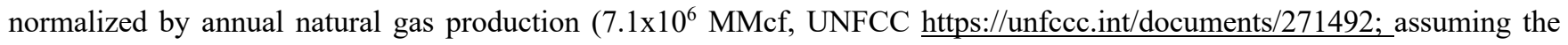
average $\mathrm{CH}_{4}$ content is $90 \%$ ) in 2019 , the national $\mathrm{O} / \mathrm{G}$ mean leakage rate is $1.7 \%$ in Canada.

\section{Comparison with field estimates for individual basins}

260 A unique feature of our work is the use of satellite observations to quantify emissions at high resolution for individual $\mathrm{O} / \mathrm{G}$ basins, building up to the national scale for the US and Canada. A number of aircraft and ground-based field campaigns previously estimated emissions from individual basins (Table S1). These field campaigns were carried out between 2013 and 2020 (with many of those field measurements taken before 2015), whereas our satellite observational period is for 20182020, which could affect the comparison. Intermittency of emissions is another factor that would affect the interpretation of results from field campaigns (Cusworth et al., 2021; Varon et al., 2021). Fig. 4 compares the basin-scale emission estimates from these field campaigns to the gridded EPA and ECCC inventories, and to our TROPOMI inversion results. The inventories are consistently lower by a factor of 1.5-3. Results from our TROPOMI inversion are more consistent with the field campaigns, especially for the large $\mathrm{O} / \mathrm{G}$ basins $\left(>0.5 \mathrm{Tg} \mathrm{a}^{-1}\right)$ such as the Permian, its Delaware sub-basin, Haynesville, and Barnett. The coefficient of determination $\left(R^{2}\right)$ between TROPOMI-derived posterior estimates and field measurements is 0.92, compared to 0.73 for the EPA and ECCC inventories. Overall, the results offer quantitative support of our TROPOMI inversion for high-emitting basins $\left(>0.5 \mathrm{Tg} \mathrm{a}^{-1}\right)$ but suggest that TROPOMI measurements provide only a limited constraint on the emission quantification of lesser-emitting basins. We examine below more broadly the parameters governing the capability of TROPOMI to quantify basin-scale emissions. 


\section{Assessing the quantification efficacy of TROPOM}

TROPOMI is designed to quantify emissions on a regional scale, and a critical question for methane emission controls is whether it can do so at the scale of individual $\mathrm{O} / \mathrm{G}$ basins. Results in Fig. $2 \mathrm{c}$ and 4 indicate successful quantification of basin-scale emissions exceeding $0.5 \mathrm{Tg} \mathrm{a}^{-1}$. The inherent TROPOMI limitations can be understood by examining the averaging kernel (AK) sensitivities of our inversion system (see Methods). The AK sensitivities (diagonal terms of the AK matrix) measure the ability of the inversion to quantify the true emissions, as defined by the ratio of posterior to prior error variances weighed by the corresponding error covariances (Brasseur, and Jacob, 2017). Our inversion assumes fixed (50\%) prior emission error standard deviation on the $0.25^{\circ} \times 0.3125^{\circ}$ grid, so that absolute prior errors scale with the magnitude of emissions and decrease with the size of the basin. On the other hand, observational errors as estimated by the residual error method (Heald et al., 2004) generally remain in the 10-20 ppb range for individual observations and decrease with the number of observations. It follows that the ability of our TROPOMI inversion to quantify basin-scale emissions increases with the magnitude of emissions and with the number of observations. The observation density is highest in the southwestern US where TROPOMI retrievals are most often successful (arid regions, clear skies, homogeneous surfaces), and thus the AK sensitivities are highest for O/G fields in those regions and in particular for the Permian (Fig. S2 and S9).

We examined more broadly the variables influencing the ability of our TROPOMI-based inversion system to quantify emissions at the basin scale. These variables include (a) emissions (prior and posterior emissions), (b) number of satellite observations, and (c) other geophysical properties and satellite retrieval parameters (e.g. the albedo, surface altitude, surface roughness). Of all these variables, emissions and the number of satellite observations show the strongest correlation with the posterior uncertainty for the $19 \mathrm{O} / \mathrm{G}$ basins; the correlation coefficient $R$ can be as high as -0.7 , a result consistent with AK sensitivities (Fig. 5, more details in Fig. S14). Results across these $\mathrm{O} / \mathrm{G}$ basins show that our inversion framework can quantify areal methane emissions with an uncertainty below $30 \%$ if the emission rates exceed $0.2 \mathrm{Tg} \mathrm{a}^{-1}$ and the number of observations exceeds $5,000 \mathrm{a}^{-1}$. If we normalize the number of observations by the basin area, it suggests that our inversion framework can quantify large basin-scale sources where the satellite data density greater than 0.3 counts $\mathrm{km}^{-2} \mathrm{a}^{-1}$ (Fig. 5). This encompasses many $\mathrm{O} / \mathrm{G}$ fields at mid-latitudes, though $\mathrm{O} / \mathrm{G}$ fields in the tropics are more of a challenge because they are often collocated with wetlands (Nigeria, Venezuela) and therefore have extensive cloudiness (Fig. S15). For areas with lower data density, a reliable quantification may need the support of other observations (e.g., other satellites, field measurements) or more accurate facility-scale information. From the data in Fig. 5, the basin-scale posterior relative uncertainty (\%) of our inversion framework can be estimated using the following equation.

$$
\mathrm{z}=-15 \log _{10} x_{1}-13 x_{2}-17\left(\mathrm{R}^{2}=0.53\right)
$$

where $z$ is the posterior relative uncertainty (\%), $x_{1}$ is the bottom-up emissions (in $\mathrm{Tg} \mathrm{a}^{-1}$ ) in each basin, and $x_{2}$ is the satellite data density (in counts $\mathrm{km}^{-2} \mathrm{a}^{-1}$ ). 
We further test this conclusion by examining these relationships in 1,000 pseudo-basins that are generated randomly with varying locations and area sizes (Fig. S16) in the US and Canada. Unlike the 19 O/G basins that are usually located in arid regions with denser observations, these 1,000 pseudo-basins can encompass more complicated satellite observing conditions and sectorial emission constitutions. As seen from Fig. S17, our inversion framework can constrain the posterior $\mathrm{O} / \mathrm{G}$ emissions with an uncertainty $<30 \%$ in areas with $\mathrm{O} / \mathrm{G}$ emission rates $>0.2-0.5 \mathrm{Tg} \mathrm{a}^{-1}$ and the number of observations is higher than $5 \times 10^{3} \mathrm{a}^{-1}$. Of all the variables, we consistently find that large emitting basins show the best statistical relationship with posterior uncertainty. This result suggests that TROPOMI can be effective in assessing large area sources, and it may be applied globally to evaluate $\mathrm{O} / \mathrm{G}$ emission inventory in areas with emissions exceeding $0.2-0.5 \mathrm{Tg} \mathrm{a}^{-1}$ and observation counts exceeding $5000 \mathrm{a}^{-1}$.

\section{Discussion}

In summary, we show that TROPOMI satellite observations can successfully quantify methane emissions from the oil and natural gas sector in the US and Canada, including major oil and natural gas basins using the combination of TROPOMI's daily coverage in cloud-free conditions and moderately high-resolution information. To demonstrate this, we conducted inversions of TROPOMI observations for 22 months at $0.25^{\circ} \times 0.3125^{\circ}$ resolution in the $\mathrm{O} / \mathrm{G}$ production basins and other O/G-emitting grid cells, accounting for over $98 \%$ of total $\mathrm{O} / \mathrm{G}$ emissions in the continental US EPA and Canada ECCC national inventories used as prior estimates for the inversion. We conducted an ensemble of inversions to determine the sensitivity of results to different weighting of observations, different prior estimates and associated uncertainties, and the addition of data quality filters. We find that national methane emissions from the $\mathrm{O} / \mathrm{G}$ sector are $12.6 \pm 2.1( \pm 2 \sigma) \mathrm{Tg} \mathrm{a}{ }^{-1}$ in the US and $2.2 \pm 0.6( \pm 2 \sigma) \mathrm{Tg} \mathrm{a}^{-1}$ in Canada, which are $80 \%$ and $40 \%$ higher than the national bottom-up inventories, respectively. About $70 \%$ of the discrepancy in the EPA inventory can be attributed to five O/G basins: the Permian, Haynesville, Anadarko, Eagle Ford and Barnett Basin, which in total account for $40 \%$ of US emissions. Our satellitederived emission estimates show good consistency with in-situ field measurements for large $\mathrm{O} / \mathrm{G}$ basins with emissions higher than $0.5 \mathrm{Tg} \mathrm{a}^{-1}$. Further examination of the error budget of the inversion suggests that our inversion framework can quantify emission rates with an uncertainty $(2 \sigma)$ better than $30 \%$ in areas with emissions exceeding $0.2-0.5 \mathrm{Tg} \mathrm{a}^{-1}$ and observation counts exceeding $5000 \mathrm{a}^{-1}$. Many large $\mathrm{O} / \mathrm{G}$ basins at mid-latitudes meet these criteria for successful source quantification with TROPOMI observations.

\section{Acknowledgments}

335 L.S. is thankful to the High Meadows Research Fellowship at EDF for supporting this work. R.G., M.O., D.Z.A., D.L. and S.P.H. at EDF were funded by the Robertson Foundation. Work at Harvard was funded by the NASA Carbon Monitoring 
System and by the United Nations Environment Program. The TROPOMI data processing was carried out on the Dutch National e-Infrastructure with the support of the SURF Cooperative. All data, code, and materials used in the analyses is available at https://doi.org/10.18170/DVN/JPKFU6.

\section{References}

Alexe, M., Bergamaschi, P., Segers, A., Detmers, R., Butz, A., Hasekamp, O., Guerlet, S., Parker, R., Boesch, H., Frankenberg, C., Scheepmaker, R. A., Dlugokencky, E., Sweeney, C., Wofsy, S. C., and Kort, E. A.: Inverse modelling of $\mathrm{CH}_{4}$ emissions for 2010-2011 using different satellite retrieval products from GOSAT and SCIAMACHY, Atmos. Chem. Phys., 15, 113-133, https://doi.org/10.5194/acp-15-113-2015, 2015.

345 Alvarez, R. A., Zavala-Araiza, D., Lyon, D. R., Allen, D. T., Barkley, Z. R., Brandt, A. R., Davis, K. J., Herndon, S. C., Jacob, D. J., Karion, A., Kort, E. A., Lamb, B. K., Lauvaux, T., Maasakkers, J. D., Marchese, A. J., Omara, M., Pacala, S. W., Peischl, J., Robinson, A. L., Shepson, P. B., Sweeney, C., Townsend-Small, A., Wofsy, S. C., and Hamburg, S. P.: Assessment of methane emissions from the U.S. oil and gas supply chain, Science, eaar7204, https://doi.org/10.1126/science.aar7204, 2018.

350 Atherton, E., Risk, D., Fougère, C., Lavoie, M., Marshall, A., Werring, J., Williams, J. P., and Minions, C.: Mobile measurement of methane emissions from natural gas developments in northeastern British Columbia, Canada, Atmos. Chem. Phys., 17, 12405-12420, https://doi.org/10.5194/acp-17-12405-2017, 2017.

Baray, S., Darlington, A., Gordon, M., Hayden, K. L., Leithead, A., Li, S.-M., Liu, P. S. K., Mittermeier, R. L., Moussa, S. G., O'Brien, J., Staebler, R., Wolde, M., Worthy, D., and McLaren, R.: Quantification of methane sources in the Athabasca

355 Oil Sands Region of Alberta by aircraft mass balance, Atmos. Chem. Phys., 18, 7361-7378, https://doi.org/10.5194/acp-187361-2018, 2018.

Baray, S., Jacob, D. J., Massakkers, J. D., Sheng, J.-X., Sulprizio, M. P., Jones, D. B. A., Bloom, A. A., and McLaren, R.: Estimating 2010-2015 Anthropogenic and Natural Methane Emissions in Canada using ECCC Surface and GOSAT Satellite Observations, Gases/Atmospheric Modelling/Troposphere/Physics (physical properties and processes), https://doi.org/10.5194/acp-2020-1195, 2021.

Bloom, A. A., Bowman, K. W., Lee, M., Turner, A. J., Schroeder, R., Worden, J. R., Weidner, R., McDonald, K. C., and Jacob, D. J.: A global wetland methane emissions and uncertainty dataset for atmospheric chemical transport models (WetCHARTs version 1.0), Geosci. Model Dev., 10, 2141-2156, https://doi.org/10.5194/gmd-10-2141-2017, 2017.

Brandt, A. R., Heath, G. A., Kort, E. A., O’Sullivan, F., Petron, G., Jordaan, S. M., Tans, P., Wilcox, J., Gopstein, A. M., 365 Arent, D., Wofsy, S., Brown, N. J., Bradley, R., Stucky, G. D., Eardley, D., and Harriss, R.: Methane Leaks from North American Natural Gas Systems, Science, 343, 733-735, https://doi.org/10.1126/science.1247045, 2014.

Brasseur, G. P. and Jacob, D. J.: Modeling of atmospheric chemistry, Cambridge University Press, 2017.

Buchwitz, M., Reuter, M., Schneising, O., Boesch, H., Guerlet, S., Dils, B., Aben, I., Armante, R., Bergamaschi, P., Blumenstock, T., Bovensmann, H., Brunner, D., Buchmann, B., Burrows, J. P., Butz, A., Chédin, A., Chevallier, F., 370 Crevoisier, C. D., Deutscher, N. M., Frankenberg, C., Hase, F., Hasekamp, O. P., Heymann, J., Kaminski, T., Laeng, A., Lichtenberg, G., De Mazière, M., Noël, S., Notholt, J., Orphal, J., Popp, C., Parker, R., Scholze, M., Sussmann, R., Stiller, G. P., Warneke, T., Zehner, C., Bril, A., Crisp, D., Griffith, D. W. T., Kuze, A., O’Dell, C., Oshchepkov, S., Sherlock, V., Suto, H., Wennberg, P., Wunch, D., Yokota, T., and Yoshida, Y.: The Greenhouse Gas Climate Change Initiative (GHG$\mathrm{CCI}$ ): Comparison and quality assessment of near-surface-sensitive satellite-derived $\mathrm{CO} 2$ and $\mathrm{CH} 4$ global data sets, Remote Sensing of Environment, 162, 344-362, https://doi.org/10.1016/j.rse.2013.04.024, 2015. 
Butz, A., Guerlet, S., Hasekamp, O., Schepers, D., Galli, A., Aben, I., Frankenberg, C., Hartmann, J.-M., Tran, H., Kuze, A., Keppel-Aleks, G., Toon, G., Wunch, D., Wennberg, P., Deutscher, N., Griffith, D., Macatangay, R., Messerschmidt, J., Notholt, J., and Warneke, T.: Toward accurate $\mathrm{CO}_{2}$ and $\mathrm{CH}_{4}$ observations from GOSAT: GOSAT CO 2 AND $\mathrm{CH}_{4}$ VALIDATION, Geophys. Res. Lett., 38, n/a-n/a, https://doi.org/10.1029/2011GL047888, 2011.

380 Chan, E., Worthy, D. E. J., Chan, D., Ishizawa, M., Moran, M. D., Delcloo, A., and Vogel, F.: Eight-Year Estimates of Methane Emissions from Oil and Gas Operations in Western Canada Are Nearly Twice Those Reported in Inventories, Environ. Sci. Technol., 54, 14899-14909, https://doi.org/10.1021/acs.est.0c04117, 2020.

Cressot, C., Chevallier, F., Bousquet, P., Crevoisier, C., Dlugokencky, E. J., Fortems-Cheiney, A., Frankenberg, C., Parker, R., Pison, I., Scheepmaker, R. A., Montzka, S. A., Krummel, P. B., Steele, L. P., and Langenfelds, R. L.: On the consistency between global and regional methane emissions inferred from SCIAMACHY, TANSO-FTS, IASI and surface measurements, Atmos. Chem. Phys., 14, 577-592, https://doi.org/10.5194/acp-14-577-2014, 2014.

Crippa, M., Solazzo, E., Huang, G., Guizzardi, D., Koffi, E., Muntean, M., Schieberle, C., Friedrich, R., and JanssensMaenhout, G.: High resolution temporal profiles in the Emissions Database for Global Atmospheric Research, Sci Data, 7, 121, https://doi.org/10.1038/s41597-020-0462-2, 2020.

390 Cusworth, D. H., Duren, R. M., Thorpe, A. K., Olson-Duvall, W., Heckler, J., Chapman, J. W., Eastwood, M. L., Helmlinger, M. C., Green, R. O., Asner, G. P., Dennison, P. E., and Miller, C. E.: Intermittency of Large Methane Emitters in the Permian Basin, Environ. Sci. Technol. Lett., 8, 567-573, https://doi.org/10.1021/acs.estlett.1c00173, 2021.

Duren, R. M., Thorpe, A. K., Foster, K. T., Rafiq, T., Hopkins, F. M., Yadav, V., Bue, B. D., Thompson, D. R., Conley, S., Colombi, N. K., Frankenberg, C., McCubbin, I. B., Eastwood, M. L., Falk, M., Herner, J. D., Croes, B. E., Green, R. O., and Miller, C. E.: California's methane super-emitters, Nature, 575, 180-184, https://doi.org/10.1038/s41586-019-1720-3, 2019.

ECCC: Canada to reduce emissions from oil and gas industry, Environment and Climate Change Canada (ECCC), Gatineau QC, 2017.

ECCC: National Inventory Report 1990-2018: Greenhouse Gas Sources and Sinks in Canada, Environment and Climate Change Canada (ECCC), Gatineau QC, 2020.

Enverus DrillingInfo: DI Desktop, didesktop.com., 2020.

EPA: Inventory of US greenhouse gas emissions and sinks: 1990-2018, 2020.

Frankenberg, C., Thorpe, A. K., Thompson, D. R., Hulley, G., Kort, E. A., Vance, N., Borchardt, J., Krings, T., Gerilowski, K., Sweeney, C., Conley, S., Bue, B. D., Aubrey, A. D., Hook, S., and Green, R. O.: Airborne methane remote measurements reveal heavy-tail flux distribution in Four Corners region, Proc Natl Acad Sci USA, 113, 9734-9739, https://doi.org/10.1073/pnas.1605617113, 2016.

Heald, C. L., Jacob, D. J., Jones, D. B. A., Palmer, P. I., Logan, J. A., Streets, D. G., Sachse, G. W., Gille, J. C., Hoffman, R. N., and Nehrkorn, T.: Comparative inverse analysis of satellite (MOPITT) and aircraft (TRACE-P) observations to estimate Asian sources of carbon monoxide: COMPARATIVE INVERSE ANALYSIS, J. Geophys. Res., 109, https://doi.org/10.1029/2004JD005185, 2004.

410 Hu, H., Hasekamp, O., Butz, A., Galli, A., Landgraf, J., Aan de Brugh, J., Borsdorff, T., Scheepmaker, R., and Aben, I.: The operational methane retrieval algorithm for TROPOMI, Atmos. Meas. Tech., 9, 5423-5440, https://doi.org/10.5194/amt-95423-2016, 2016. 
IPCC: Climate Change 2021: The Physical Science Basis. Contribution of Working Group I to the Sixth Assessment Report of the Intergovernmental Panel on Climate Change [Masson-Delmotte, V., P. Zhai, A. Pirani, S. L. Connors, C. Péan, S. Berger, N. Caud, Y. Chen, L. Goldfarb, M. I. Gomis, M. Huang, K. Leitzell, E. Lonnoy, J. B. R. Matthews, T. K. Maycock, T. Waterfield, O. Yelekçi, R. Yu and B. Zhou (eds.)]., Cambridge University Press, 2021.

Irakulis-Loitxate, I., Guanter, L., Liu, Y.-N., Varon, D. J., Maasakkers, J. D., Zhang, Y., Chulakadabba, A., Wofsy, S. C., Thorpe, A. K., Duren, R. M., Frankenberg, C., Lyon, D. R., Hmiel, B., Cusworth, D. H., Zhang, Y., Segl, K., Gorroño, J., Sánchez-García, E., Sulprizio, M. P., Cao, K., Zhu, H., Liang, J., Li, X., Aben, I., and Jacob, D. J.: Satellite-based survey of extreme methane emissions in the Permian basin, Sci. Adv., 7, eabf4507, https://doi.org/10.1126/sciadv.abf4507, 2021.

Johnson, M. R., Tyner, D. R., Conley, S., Schwietzke, S., and Zavala-Araiza, D.: Comparisons of Airborne Measurements and Inventory Estimates of Methane Emissions in the Alberta Upstream Oil and Gas Sector, Environ. Sci. Technol., 51, 13008-13017, https://doi.org/10.1021/acs.est.7b03525, 2017.

Kort, E. A., Frankenberg, C., Costigan, K. R., Lindenmaier, R., Dubey, M. K., and Wunch, D.: Four corners: The largest US 425 methane anomaly viewed from space: Four Corners: largest US methane anomaly, Geophys. Res. Lett., 41, 6898-6903, https://doi.org/10.1002/2014GL061503, 2014.

Lorente, A., Borsdorff, T., Butz, A., Hasekamp, O., aan de Brugh, J., Schneider, A., Hase, F., Kivi, R., Wunch, D., Pollard, D. F., Shiomi, K., Deutscher, N. M., Velazco, V. A., Roehl, C. M., Wennberg, P. O., Warneke, T., and Landgraf, J.: Methane retrieved from TROPOMI: improvement of the data product and validation of the first two years of measurements, Gases/Remote Sensing/Data Processing and Information Retrieval, https://doi.org/10.5194/amt-2020-281, 2020.

Lu, X., Jacob, D. J., Zhang, Y., Maasakkers, J. D., Sulprizio, M. P., Shen, L., Qu, Z., Scarpelli, T. R., Nesser, H., Yantosca, R. M., Sheng, J., Andrews, A., Parker, R. J., Boesch, H., Bloom, A. A., and Ma, S.: Global methane budget and trend, 20102017: complementarity of inverse analyses using in situ (GLOBALVIEWplus CH\&lt;sub\&gt;4\&lt;/sub\&gt; ObsPack) and satellite (GOSAT) observations, Atmos. Chem. Phys., 21, 4637-4657, https://doi.org/10.5194/acp-21-4637-2021, $2021 \mathrm{a}$.

435 Lu, X., Jacob, D. J., Wang, H., Maasakkers, J. D., Zhang, Y., Scarpelli, T. R., Shen, L., Qu, Z., Sulprizio, M. P., Nesser, H., Bloom, A. A., Ma, S., Worden, J. R., Fan, S., Parker, R. J., Boesch, H., Gautam, R., Gordon, D., Moran, M. D., Reuland, F., and Villasana, C. A. O.: Methane emissions in the United States, Canada, and Mexico: Evaluation of national methane emission inventories and sectoral trends by inverse analysis of in situ (GLOBALVIEWplus CH4 ObsPack) and satellite (GOSAT) atmospheric observations, Atmos. Chem. Phys. Discuss., https://doi.org/10.5194/acp-2021-671, $2021 \mathrm{~b}$.

440 Lucchesi, R.: File Specification for GEOS-5 FP. GMAO Office Note No. 4 (Version 1.0), http://gmao.gsfc.nasa.gov/pubs/office_notes, 2013.

Lyon, D. R., Hmiel, B., Gautam, R., Omara, M., Roberts, K. A., Barkley, Z. R., Davis, K. J., Miles, N. L., Monteiro, V. C., Richardson, S. J., Conley, S., Smith, M. L., Jacob, D. J., Shen, L., Varon, D. J., Deng, A., Rudelis, X., Sharma, N., Story, K. T., Brandt, A. R., Kang, M., Kort, E. A., Marchese, A. J., and Hamburg, S. P.: Concurrent variation in oil and gas methane 445 emissions and oil price during the COVID-19 pandemic, Atmos. Chem. Phys., 21, 6605-6626, https://doi.org/10.5194/acp21-6605-2021, 2021.

Ma, S., Worden, J. R., Bloom, A. A., Zhang, Y., Poulter, B., Cusworth, D. H., Yin, Y., Pandey, S., Maasakkers, J. D., Lu, X., Shen, L., Sheng, J., Frankenberg, C., Miller, C. E., and Jacob, D. J.: Satellite Constraints on the Latitudinal Distribution and Temperature Sensitivity of Wetland Methane Emissions, AGU Advances, 2, https://doi.org/10.1029/2021AV000408, 2021. 
Maasakkers, J. D., Jacob, D. J., Sulprizio, M. P., Turner, A. J., Weitz, M., Wirth, T., Hight, C., DeFigueiredo, M., Desai, M., Schmeltz, R., Hockstad, L., Bloom, A. A., Bowman, K. W., Jeong, S., and Fischer, M. L.: Gridded National Inventory of U.S. Methane Emissions, Environ. Sci. Technol., 50, 13123-13133, https://doi.org/10.1021/acs.est.6b02878, 2016.

Maasakkers, J. D., Jacob, D. J., Sulprizio, M. P., Scarpelli, T. R., Nesser, H., Sheng, J.-X., Zhang, Y., Hersher, M., Bloom, A. A., Bowman, K. W., Worden, J. R., Janssens-Maenhout, G., and Parker, R. J.: Global distribution of methane emissions, emission trends, and $\mathrm{OH}$ concentrations and trends inferred from an inversion of GOSAT satellite data for 2010-2015, Atmos. Chem. Phys., 19, 7859-7881, https://doi.org/10.5194/acp-19-7859-2019, 2019.

Maasakkers, J. D., Jacob, D. J., Sulprizio, M. P., Scarpelli, T. R., Nesser, H., Sheng, J., Zhang, Y., Lu, X., Bloom, A. A., Bowman, K. W., Worden, J. R., and Parker, R. J.: 2010-2015 North American methane emissions, sectoral contributions, and trends: a high-resolution inversion of GOSAT observations of atmospheric methane, Atmos. Chem. Phys., 21, 43394356, https://doi.org/10.5194/acp-21-4339-2021, 2021.

MacKay, K., Lavoie, M., Bourlon, E., Atherton, E., O’Connell, E., Baillie, J., Fougère, C., and Risk, D.: Methane emissions from upstream oil and gas production in Canada are underestimated, Sci Rep, 11, 8041, https://doi.org/10.1038/s41598-02187610-3, 2021.

465 Myhre, G., Shindell, D., Bréon, F. M., Collins, M., Fuglestvedt, J., Huang, J., Koch, D., Lamarque, J.-F., Lee, D., Mendoza, B., Nakajima, T., Robock, A., Stephens, G., Takemura, T., and Zhang, H.: Anthropogenic and natural radiative forcing. In Climate Change 2013: The Physical Science Basis. Contribution of Working Group I to the Fifth Assessment Report of the Intergovernmental Panel on Climate Change., Cambridge University Press, 659-740, 2013.

Ocko, I. B., Sun, T., Shindell, D., Oppenheimer, M., Hristov, A. N., Pacala, S. W., Mauzerall, D. L., Xu, Y., and Hamburg, 470 S. P.: Acting rapidly to deploy readily available methane mitigation measures by sector can immediately slow global warming, Environ. Res. Lett., 16, 054042, https://doi.org/10.1088/1748-9326/abf9c8, 2021.

Omara, M., Zimmerman, N., Sullivan, M. R., Li, X., Ellis, A., Cesa, R., Subramanian, R., Presto, A. A., and Robinson, A. L.: Methane Emissions from Natural Gas Production Sites in the United States: Data Synthesis and National Estimate, Environ. Sci. Technol., 52, 12915-12925, https://doi.org/10.1021/acs.est.8b03535, 2018.

475 Pandey, S., Gautam, R., Houweling, S., van der Gon, H. D., Sadavarte, P., Borsdorff, T., Hasekamp, O., Landgraf, J., Tol, P., van Kempen, T., Hoogeveen, R., van Hees, R., Hamburg, S. P., Maasakkers, J. D., and Aben, I.: Satellite observations reveal extreme methane leakage from a natural gas well blowout, Proc Natl Acad Sci USA, 116, 26376-26381, https://doi.org/10.1073/pnas.1908712116, 2019.

Parker, R. J., Webb, A., Boesch, H., Somkuti, P., Barrio Guillo, R., Di Noia, A., Kalaitzi, N., Anand, J. S., Bergamaschi, P., 480 Chevallier, F., Palmer, P. I., Feng, L., Deutscher, N. M., Feist, D. G., Griffith, D. W. T., Hase, F., Kivi, R., Morino, I., Notholt, J., Oh, Y.-S., Ohyama, H., Petri, C., Pollard, D. F., Roehl, C., Sha, M. K., Shiomi, K., Strong, K., Sussmann, R., Té, Y., Velazco, V. A., Warneke, T., Wennberg, P. O., and Wunch, D.: A decade of GOSAT Proxy satellite CH\&lt;sub\&gt;4\&lt;/sub\&gt; observations, Earth Syst. Sci. Data, 12, 3383-3412, https://doi.org/10.5194/essd-12-33832020, 2020.

485 Robertson, A. M., Edie, R., Field, R. A., Lyon, D., McVay, R., Omara, M., Zavala-Araiza, D., and Murphy, S. M.: New Mexico Permian Basin Measured Well Pad Methane Emissions Are a Factor of 5-9 Times Higher Than U.S. EPA Estimates, Environ. Sci. Technol., 54, 13926-13934, https://doi.org/10.1021/acs.est.0c02927, 2020.

Rutherford, J. S., Sherwin, E. D., Ravikumar, A. P., Heath, G. A., Englander, J., Cooley, D., Lyon, D., Omara, M., Langfitt, Q., and Brandt, A. R.: Closing the methane gap in US oil and natural gas production emissions inventories, Nat Commun, 
Scarpelli, T. R., Jacob, D. J., Maasakkers, J. D., Sulprizio, M. P., Sheng, J.-X., Rose, K., Romeo, L., Worden, J. R., and Janssens-Maenhout, G.: A global gridded $\left(0.1^{\circ} \times 0.1^{\circ}\right)$ inventory of methane emissions from oil, gas, and coal exploitation based on national reports to the United Nations Framework Convention on Climate Change, Earth Syst. Sci. Data, 12, 563575, https://doi.org/10.5194/essd-12-563-2020, 2020.

495 Scarpelli, T. R., Jacob, D. J., Moran, M., Reuland, F., and Gordon, D.: A gridded inventory of Canada's anthropogenic methane emissions, 2021.

Schneising, O., Buchwitz, M., Reuter, M., Vanselow, S., Bovensmann, H., and Burrows, J. P.: Remote sensing of methane leakage from natural gas and petroleum systems revisited, Atmos. Chem. Phys., 20, 9169-9182, https://doi.org/10.5194/acp20-9169-2020, 2020.

500 Shen, L., Zavala-Araiza, D., Gautam, R., Omara, M., Scarpelli, T., Sheng, J., Sulprizio, M. P., Zhuang, J., Zhang, Y., Qu, Z., Lu, X., Hamburg, S. P., and Jacob, D. J.: Unravelling a large methane emission discrepancy in Mexico using satellite observations, Remote Sensing of Environment, 260, 112461, https://doi.org/10.1016/j.rse.2021.112461, 2021.

Turner, A. J. and Jacob, D. J.: Balancing aggregation and smoothing errors in inverse models, Atmos. Chem. Phys., 15, 7039-7048, https://doi.org/10.5194/acp-15-7039-2015, 2015.

505 Turner, A. J., Jacob, D. J., Wecht, K. J., Maasakkers, J. D., Lundgren, E., Andrews, A. E., Biraud, S. C., Boesch, H., Bowman, K. W., Deutscher, N. M., Dubey, M. K., Griffith, D. W. T., Hase, F., Kuze, A., Notholt, J., Ohyama, H., Parker, R., Payne, V. H., Sussmann, R., Sweeney, C., Velazco, V. A., Warneke, T., Wennberg, P. O., and Wunch, D.: Estimating global and North American methane emissions with high spatial resolution using GOSAT satellite data, Atmos. Chem. Phys., 15, 7049-7069, https://doi.org/10.5194/acp-15-7049-2015, 2015.

510 Varon, D. J., Jervis, D., McKeever, J., Spence, I., Gains, D., and Jacob, D. J.: High-frequency monitoring of anomalous methane point sources with multispectral Sentinel-2 satellite observations, Atmos. Meas. Tech., 14, 2771-2785, https://doi.org/10.5194/amt-14-2771-2021, 2021.

Veefkind, J. P., Aben, I., McMullan, K., Förster, H., de Vries, J., Otter, G., Claas, J., Eskes, H. J., de Haan, J. F., Kleipool, Q., van Weele, M., Hasekamp, O., Hoogeveen, R., Landgraf, J., Snel, R., Tol, P., Ingmann, P., Voors, R., Kruizinga, B.,

515 Vink, R., Visser, H., and Levelt, P. F.: TROPOMI on the ESA Sentinel-5 Precursor: A GMES mission for global observations of the atmospheric composition for climate, air quality and ozone layer applications, Remote Sensing of Environment, 120, 70-83, https://doi.org/10.1016/j.rse.2011.09.027, 2012.

Wecht, K. J., Jacob, D. J., Frankenberg, C., Jiang, Z., and Blake, D. R.: Mapping of North American methane emissions with high spatial resolution by inversion of SCIAMACHY satellite data, J. Geophys. Res. Atmos., 119, 7741-7756, https://doi.org/10.1002/2014JD021551, 2014.

Wunch, D., Wennberg, P. O., Toon, G. C., Connor, B. J., Fisher, B., Osterman, G. B., Frankenberg, C., Mandrake, L., O’Dell, C., Ahonen, P., Biraud, S. C., Castano, R., Cressie, N., Crisp, D., Deutscher, N. M., Eldering, A., Fisher, M. L., Griffith, D. W. T., Gunson, M., Heikkinen, P., Keppel-Aleks, G., Kyrö, E., Lindenmaier, R., Macatangay, R., Mendonca, J., Messerschmidt, J., Miller, C. E., Morino, I., Notholt, J., Oyafuso, F. A., Rettinger, M., Robinson, J., Roehl, C. M., Salawitch,

525 R. J., Sherlock, V., Strong, K., Sussmann, R., Tanaka, T., Thompson, D. R., Uchino, O., Warneke, T., and Wofsy, S. C.: A method for evaluating bias in global measurements of CO\&lt;sub\&gt;2\&lt;/sub\&gt; total columns from space, Atmos. Chem. Phys., 11, 12317-12337, https://doi.org/10.5194/acp-11-12317-2011, 2011.

Zavala-Araiza, D., Omara, M., Gautam, R., Smith, M. L., Pandey, S., Aben, I., Almanza-Veloz, V., Conley, S., Houweling, S., Kort, E. A., Maasakkers, J. D., Molina, L. T., Pusuluri, A., Scarpelli, T., Schwietzke, S., Shen, L., Zavala, M., and 
https://doi.org/10.5194/acp-2022-155

Preprint. Discussion started: 7 March 2022

(c) Author(s) 2022. CC BY 4.0 License.

(c) (i)

530 Hamburg, S. P.: A tale of two regions: methane emissions from oil and gas production in offshore/onshore Mexico, Environ. Res. Lett., 16, 024019, https://doi.org/10.1088/1748-9326/abceeb, 2021.

Zhang, Y., Gautam, R., Pandey, S., Omara, M., Maasakkers, J. D., Sadavarte, P., Lyon, D., Nesser, H., Sulprizio, M. P., Varon, D. J., Zhang, R., Houweling, S., Zavala-Araiza, D., Alvarez, R. A., Lorente, A., Hamburg, S. P., Aben, I., and Jacob, D. J.: Quantifying methane emissions from the largest oil-producing basin in the United States from space, Sci. Adv., 6, 535 eaaz5120, https://doi.org/10.1126/sciadv.aaz5120, 2020.

Zhang, Y., Jacob, D. J., Lu, X., Maasakkers, J. D., Scarpelli, T. R., Sheng, J.-X., Shen, L., Qu, Z., Sulprizio, M. P., Chang, J., Bloom, A. A., Ma, S., Worden, J., Parker, R. J., and Boesch, H.: Attribution of the accelerating increase in atmospheric methane during 2010-2018 by inverse analysis of GOSAT observations, Atmos. Chem. Phys., 21, 3643-3666, https://doi.org/10.5194/acp-21-3643-2021, 2021. 
TROPOMI methane data and oil/gas emissions in the US and Canada

(a) TROPOMI XCH4, elevation corrected

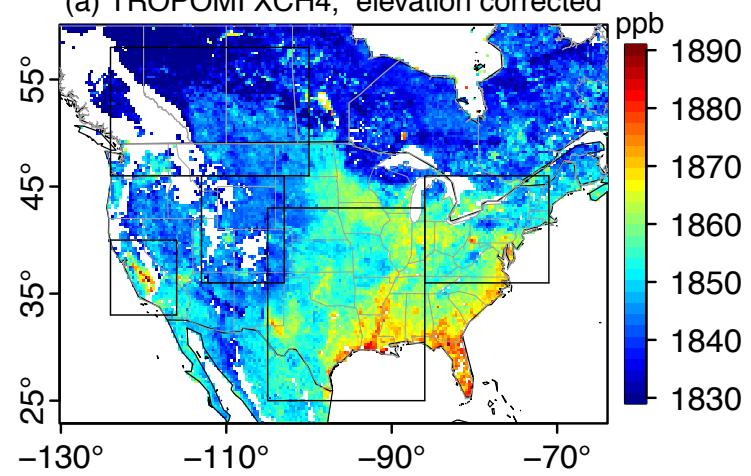

(b) Gridded EPA and ECCC oil/gas emissions in 2018

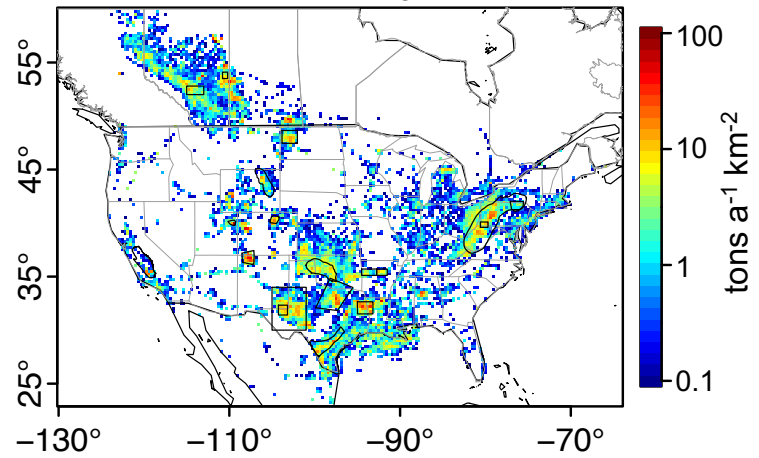

545 Figure 1. TROPOMI methane observations and prior estimates of oil and natural gas emissions in the US and Canada. (a) TROPOMI satellite observations of column-averaged dry methane mixing ratio (XCH4) averaged from May 2018 to February 2020 , mapped to $2.25^{\circ} \times 0.3125^{\circ}$ resolution and corrected for surface topography as $7 \mathrm{ppb} / \mathrm{km}$ (Kort et al., 2014). We conduct the inversions for the five rectangular domains shown in black that account for over $98 \%$ of $\mathrm{O} / \mathrm{G}$ emissions in the continental US and Canada. (b) Gridded national inventory emissions from the oil and natural gas sector in the US and Canada in 2018 used as prior estimates in our inversion of TROPOMI observations. Gridcells with emission fluxes $<0.1$ tons $\mathrm{a}^{-1} \mathrm{~km}^{-2}$ are shown as white. The boundaries of the 19 major $\mathrm{O} / \mathrm{G}$ basins are shown on the map and the names of these basins can be found in Fig. S11. 


\section{Corrections to gridded O/G EPA and ECCC inventories from TROPOMI inversion}

(a) Correction factors

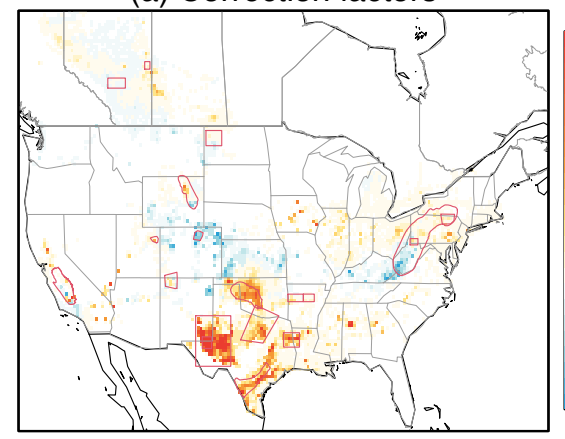

(b) Posterior emissions

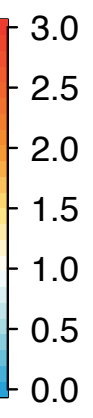

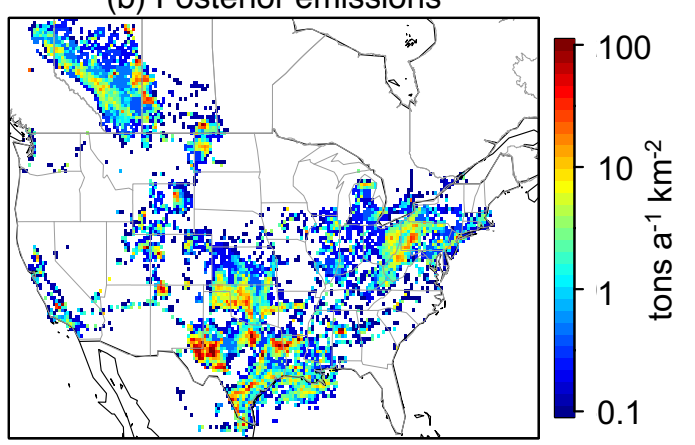

(c) Prior and posterior emissions in major oil/gas basins

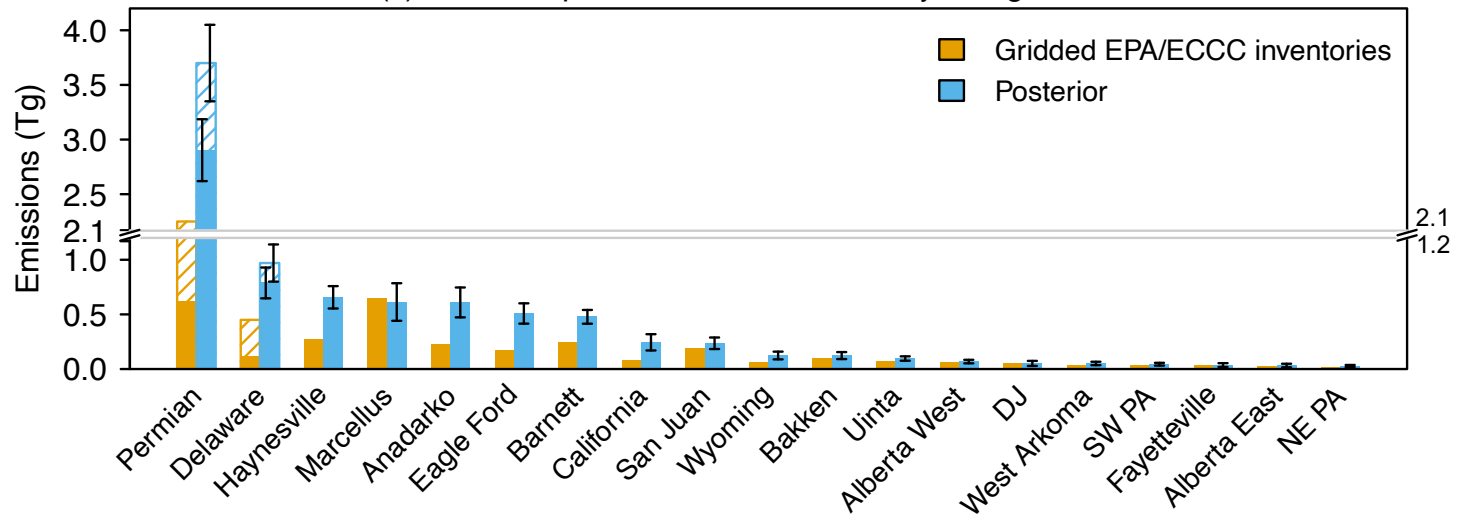

Figure 2. Corrections to oil and natural gas methane emissions in the US EPA and Canada ECCC national inventories from the inversion of TROPOMI methane observations (May 2018 - February 2020). (a) Posterior correction factors to the gridded national inventory estimates shown in Fig. $1 \mathrm{~b}$ and used as prior estimates in the inversion. The boundaries of the 19 major $\mathrm{O} / \mathrm{G}$ basins are shown on the map and the names of these basins can be found in Fig. S11. (b) Posterior $\mathrm{O} / \mathrm{G}$ methane emissions. For (a) and (b), gridcells with prior $\mathrm{O} / \mathrm{G}$ emissions $<0.1$ tons $\mathrm{a}^{-1} \mathrm{~km}^{-2}$ are shown as white (consistent with Fig. 1b). (c) Prior and posterior emissions in the 19 oil and gas basins, arranged in decreasing order of posterior emissions. Delaware is a sub-region of the Permian basin. Vertical bars indicate the 2x error standard deviations from the inversion ensemble. Striped bars for the Permian and Delaware basins show the results of an inversion where the prior estimate of emissions from the oil and gas production sector was increased by a factor of 4 from the EPA inventory, reflecting previous evidence that the EPA inventory is too low. 
National estimates of oil/gas methane emissions

(a) United States

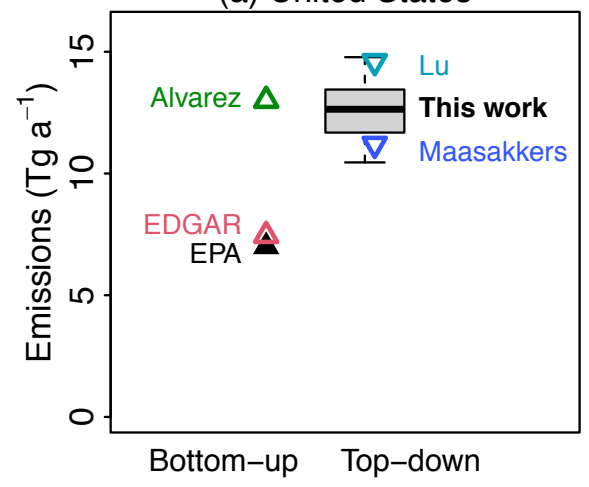

(b) Canada

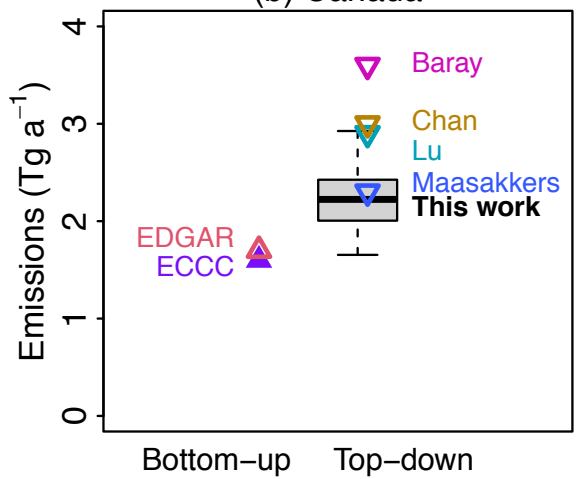

Figure 3. Bottom-up and top-down estimates of national oil and natural gas methane emissions in the US and

Canada. Estimates from this work are shown as quantile plots for the inversion ensemble. The top and bottom of the box are the 25th and 75th percentile, the vertical bars are for the minimum and maximum, and the centre line is the 50th percentile. Mean emissions \pm 2 standard deviations from the inversion ensemble are $12.6 \pm 2.1 \mathrm{Tg} \mathrm{a}^{-1}$ for the US and $2.2 \pm 0.6 \mathrm{Tg} \mathrm{a}^{-1}$ for Canada. Symbols show previous estimates including EPA (2020) for 2018 (which equals the prior estimate for our work), EDGAR v6.0 (Crippa et al., 2020) for 2018, Alvarez et al. (2018) for 2015, Maasakkers et al. (2021) for 2010-2015, Lu et al. (2021b) for 2010-2017, ECCC (2020) for 2018 (used as prior estimate for our work), Baray et al. (2021) for 2010-2015, and Chan et al. (2020) for 2010-2017. Maasakkers et al. (2021) and Lu et al. (2021b) did not include the O/G emissions in Alaska so we add $0.1 \mathrm{Tg} \mathrm{a}^{-1}$ of emissions (EPA, 2020; Maasakkers et al., 2016) here to obtain the US national total. 
https://doi.org/10.5194/acp-2022-155

Preprint. Discussion started: 7 March 2022

(c) Author(s) 2022. CC BY 4.0 License.

(c) (i)

Methane emissions from oil/gas basins in the US and Canada
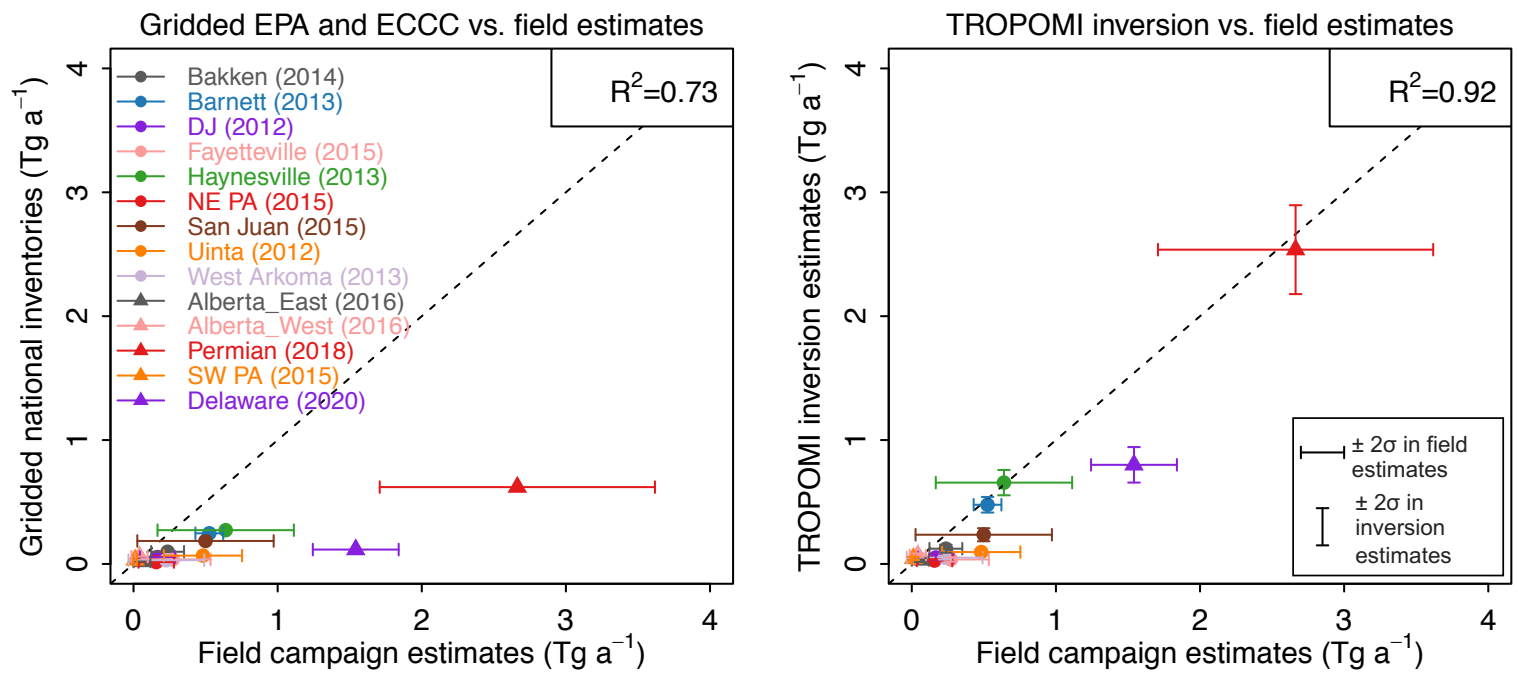

Figure 4. Methane emissions from 14 oil and natural gas production basins in the US. Estimates from field campaigns are compared to the gridded EPA and ECCC inventories for the US and Canada (left panel) and to results from our TROPOMI inversion using these inventories as prior estimates (right panel). The 1:1 line is dashed and coefficients of determination $\left(\mathrm{R}^{2}\right)$ are shown inset. More details including references for the field campaigns can be found in Table S1.

585 Circles represent the same 9 basins in Alvarez et al. (2018) and triangles are the new basins included in this study. 
(a) TROPOMI obs counts

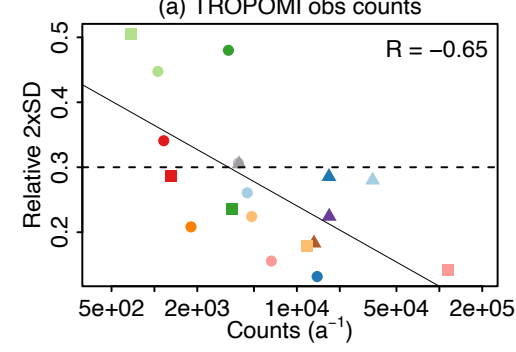

(d) Posterior emissions

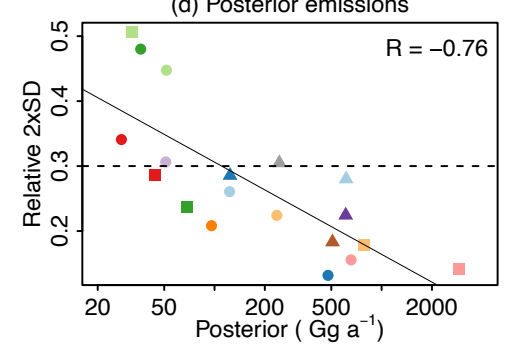

(b) TROPOMI obs density

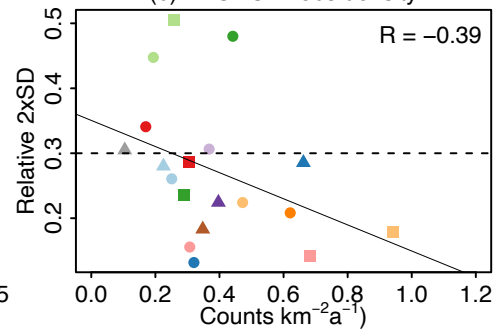

(e) Averaging kernel sensitivities

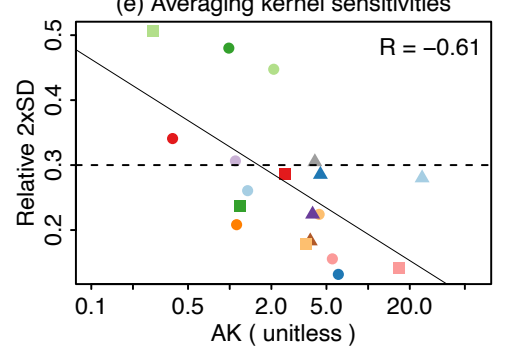

(c) Prior emissions

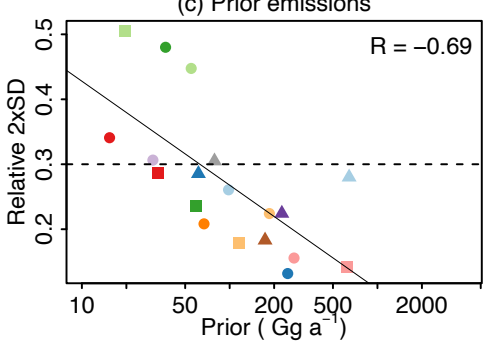

- Barnett

- DJ

- Fayetteville

- Haynesville

- NE PA

- San Juar

- Uinta

- West Arkoma

- Anadarko

- California

\ Eagle Ford

$\triangle$ Marcellus

- Wyoming

- Alberta East

- Alberta West

- Permian

- SW PA

Figure 5. Relationship of relative standard deviation (we use $2 \sigma$ here) of satellite-derived posterior estimates with different variables, including (a) the number of TROPOMI observations per year, (b) the satellite observation density, (c) prior emissions, (d) posterior emissions, and (e) averaging kernel sensitivities. The correlation coefficients are shown inset. The boundaries of 19 oil/gas basins are overlain on the map and the names of these basins can be found in Fig. S11. 